\title{
EPIDEMIOLOGICAL SURVEY ON EFFECT OF EMF EMITTED BY PHOTOCOPY MACHINES GENERALLY USED IN DHAKA CITY BANGLADESH
}

\author{
Munima Haque $^{1}$, Md. Quamruzzaman ${ }^{2}$ \\ ${ }^{1}$ Assistant Professor, Department of EEE, Southeast University, Dhaka, Bangladesh \\ ${ }^{2}$ Associate Professor, Department of EEE, Southeast University, Dhaka, Bangladesh
}

\begin{abstract}
Significant concerns has been raised about possible health effects from exposure to radiofrequency (RF) electromagnetic fields specially after the rapid introduction of modern amnesties specially the mobile telecommunication systems. The biological effects of low level EMF and a possible potential relation various diseases specially blood cancer causation are controversial. There are many epidemiological studies of the possible adverse health effects associated with environmental exposure to extremely low frequency $(0-300 \mathrm{~Hz})$ non-ionizing radiation such as that emitted by power cables and electrical substations linking such exposure to leukemia, brain cancer, male breast cancer, skin cancer and eye melanoma. Far less attention has been paid to health hazards from environmental exposure to radiation in $R F$ range $(100 \mathrm{kHz}-300 \mathrm{GHz})$ at field strengths much below to these required to produce thermal effects. Laboratory studies in this area have also been confusing and conflicting. While some animal studies suggest that RF fields accelerate the development of cancers, other studies found no carcinogenic effect. Obviously, there is an urgent need for extensive, well conducted epidemiological and laboratory studies.
\end{abstract}

Photocopy machines are being used all over the world as it has made the life easy for academic, office, business. Hundreds of photocopy machines are also being used in Bangladesh. EMF is also emitted by photocopy machines. There has been no such study performed in Bangladesh. The data were collected from various places in Dhaka city, Bangladesh: Banani Super Market, Mohakhali, Farmgate Green Road, Nilkhet and Uttara. Both Electric and Magnetic fields were measured for photocopy machines. Both epidemiological survey and EMF measurements were done for these locations. These results showed that in many cases the magnetic field radiated from the different sources are greater than the threshold limit and photocopier operators suffered from various types of ailments like indigestion, vomit, insomnia, pain in hands and legs, stomach ache, mental depression, skin disease, cataract, sexual problems, hairs turning white etc. due to prolonged exposure to EMF. In many of the photocopier shops the operators were working in congested space with lots of machineries around. There are many devices and power lines around them, having a congested environment and low circulation of air. Also smoking contributed to their overall health problems.

Keywords: EMR, NIR, WHO, ICNIRP, IARC, ITU, DNA.

\section{INTRODUCTION}

It is well known that electricity is the main source for the development of modern civilization. At the same time, it is also known to the people about the adverse effects of varying degrees of Electro-Magnetic Fields (EMF) commonly known as non-ionizing radiation (NIR) which do not ionize the media like that of ionizing radiation (i.e. $\alpha, \beta$ and $\gamma$, etc.) It is reported by the scientists that high power transmission lines [1][2], computer monitor/video display unit, radio waves of different frequencies in (extremely low frequency to microwaves) telecommunication, satellite, radar etc. also cause harm to living systems [3][4], especially in human beings for example. It is proven that high power transmission lines cause human health hazards rather than a common electrocution. Even there are evidences that the cause of clinical depression and commitment of suicide are related with the emission from the power lines [5][6]. There are several epidemiological survey reports that occupational hazards like risk of developing Acute Myeloid Leukemia (AML) may occur among the people working in the field of telecommunication. Cancerous thyroid tumor, suppression of T- lymphocyte cell etc. are also found to occur among the persons exposed to non-ionizing radiation.

Photocopy machine is one of the widely used machines in Bangladesh which radiates NIR. The workers/machine operators working for 8-10 hours a day standing beside the machine without any precautionary measures are the focal point of this paper. There have been various papers published on EMF of radio, TV etc. but not much on photocopy machines. There are hundreds of machine operators working all over Bangladesh. People nowadays are very much used to get photocopies of any things specially students' photo copy from teacher's note, books, journals, magazine, documents etc. 
There are basically three types of photocopier machines. One with heating effect, another dot and the other type is laser copier. Most current photocopier machines use a technology called xerography, it is a dry process that uses electrostatic charges on a light sensitive photoreceptor to first attract and then transfer toner particles (a powder) onto paper in the form of an image. [7] Heat, pressure or a combination of both is then used to fuse the toner onto the paper. There are other technologies such as inkjet but xerography is standard for office copying. Some devices sold as photocopiers have replaced the drum-based process with inkjet or transfer film technology. There are also color photocopiers. There is an increase in digital technology, which replaces the older analog technology. With digital copying machine, the copier consists of both an integrated scanner and a laser printer. Most of the laser printers commercially used in Dhaka Bangladesh use ultraviolet light.

Exposure to ultraviolet light has side effects. At the beginning of photocopying era, the sensitizing light source was filtered green to match the optimal sensitivity of the photoconductive surface. Therefore, this filtering removed all ultraviolet [8]. Recently, a variety of light sources are used. As glass can transmit ultraviolet rays between 325 and 4000 nanometers, copiers with ultra-violet producing lights (e.g. xenon flash, halogen, fluorescent). These expose documents to some ultraviolet. [8]. There has been some concern related to emissions from photocopier machines which uses selenium and ozone and fumes from heated toner. [9][10]

\section{METHODS}

A magnetic Science International MF meter (Serial No 624335) was used for measuring the magnetic field values for the various photocopy machines. A Cughill Field Mouse for Biohazard Awareness was used for measuring the threshold values for both electric field and magnetic field around the machines. This Cughill Field Mouse instrument was designed by Dr. Roger Coghill of UK. The students filled the measurement table for measuring the photocopy machines.

\section{RESULTS}

\subsection{Epidemiological Survey}

Findings at different EMF sources: All the readings were taken from various parts of Dhaka, Bangladesh. In Table-1, epidemiological survey data were collected from the Banani Super Market Dhaka from 5 photocopier shops. The operators were asked questions form questionnaire forms regarding their age, working years, number of hours working per day, smoker/non-smoker, various symptoms of their health and other observations. These data from table-1 Banani Super Market, Dhaka were taken on the date 12.12.2013

Table-1: Photocopy Operators at Banani Super Market, Dhaka (12.12.2013)

\begin{tabular}{|c|c|c|c|c|c|c|}
\hline S.N. & $\begin{array}{l}\text { Age } \\
\text { (years) }\end{array}$ & $\begin{array}{l}\text { Working } \\
\text { years }\end{array}$ & $\begin{array}{l}\text { Working } \\
\text { Hours/day }\end{array}$ & Smoker? & Symptoms & Other observations \\
\hline 1 & 46 & 10 & 3 & No & $\begin{array}{l}\text { Indigestion, insomnia, } \\
\text { cataract, pain in legs \& } \\
\text { wrists, mental depression }\end{array}$ & Depressed \& tense \\
\hline 2 & 18 & 1 & 10 & $\begin{array}{l}\text { Yes } \\
(20 / \text { day })\end{array}$ & No symptoms & $\begin{array}{l}\text { Young \& seems he is } \\
\text { suffering from some } \\
\text { sickness, he is not } \\
\text { concerned about it }\end{array}$ \\
\hline 3 & 29 & 15 & 12 & $\begin{array}{l}\text { Yes } \\
\text { (10/day) }\end{array}$ & $\begin{array}{l}\text { Indigestion, insomnia, } \\
\text { pain in hands, cataract }\end{array}$ & $\begin{array}{l}\text { Works in congested } \\
\text { space with lots of } \\
\text { machineries around }\end{array}$ \\
\hline 4 & 27 & 1.5 & 11 & $\begin{array}{l}\text { Yes } \\
\text { (10/day) }\end{array}$ & $\begin{array}{l}\text { Stomach ache, pain in } \\
\text { hands, sexual problems }\end{array}$ & $\begin{array}{l}\text { Lots of device \& } \\
\text { power lines around } \\
\text { him, congested space } \\
\& \text { air circulation is } \\
\text { very low }\end{array}$ \\
\hline 5 & 29 & 13 & 12 & $\begin{array}{l}\text { Yes } \\
(10 / \text { day })\end{array}$ & $\begin{array}{l}\text { Depression but not so } \\
\text { deep }\end{array}$ & $\begin{array}{l}\text { He is young, gives } \\
\text { time in physical } \\
\text { exercise regularly }\end{array}$ \\
\hline
\end{tabular}

In Table-2, epidemiological survey data were collected from the Mohakhali Dhaka from 3 photocopier shops. The operators were asked questions form questionnaire forms regarding their age, working years, number of hours working per day, smoker/non-smoker, various symptoms of their health and other observations. These data from table-2 Mohakhali, Dhaka were taken on the date 1.04.2013 
Table-2: Photocopy Operators at Mohakhali, Dhaka (1.04.2013)

\begin{tabular}{|l|l|l|l|l|l|l|}
\hline S.N. & $\begin{array}{l}\text { Age } \\
\text { (years) }\end{array}$ & $\begin{array}{l}\text { Working } \\
\text { years }\end{array}$ & $\begin{array}{l}\text { Working } \\
\text { Hours/day }\end{array}$ & Smoker? & Symptoms & Other observations \\
\hline 1 & 24 & 1 & 10 & $\begin{array}{l}\text { Yes (5/day) } \\
5 \text { years }\end{array}$ & $\begin{array}{l}\text { Indigestion, insomnia, cataract, } \\
\text { pain in legs, mental depression, } \\
\text { stomach ache }\end{array}$ & $\begin{array}{l}\text { Stomach ache and } \\
\text { pain in legs common } \\
\text { problem }\end{array}$ \\
\hline 2 & 20 & 4 months & 12 & No & $\begin{array}{l}\text { Insomnia, pain in hands \& } \\
\text { legs, mental depression, } \\
\text { stomach ache, skin disease }\end{array}$ & $\begin{array}{l}\text { Pain in hands and } \\
\text { legs common } \\
\text { common }\end{array}$ \\
\hline 3 & 30 & 2 & 12 & $\begin{array}{l}\text { Yes } \\
(10 / \text { day) }\end{array}$ & $\begin{array}{l}\text { Indigestion, insomnia, pain in } \\
\text { hands, skin disease feels insomnia }\end{array}$ & $\begin{array}{l}\text { He fand pain in hands } \\
\text { and }\end{array}$ \\
\hline
\end{tabular}

In Table-3, epidemiological survey data were collected from Farmgate Green Road Dhaka from 9 photocopier shops. The operators were asked questions form questionnaire forms regarding their age, working years, number of hours working per day, smoker/non-smoker, various symptoms of their health and other observations. These data from table-3 Farmgate, Green Road Dhaka were taken on the date 9.11.2013

Table-3: Photocopy Operators at Farmgate, Green Road Dhaka (9.11.2013)

\begin{tabular}{|c|c|c|c|c|c|c|}
\hline S.N. & $\begin{array}{l}\text { Age } \\
\text { (years) }\end{array}$ & $\begin{array}{l}\text { Working } \\
\text { years }\end{array}$ & $\begin{array}{l}\text { Working } \\
\text { Hours/day }\end{array}$ & Smoker? & Symptoms & Other observations \\
\hline 1 & 30 & 5 & 13 & $\begin{array}{l}\text { Yes } \\
(11-14 / \text { day })\end{array}$ & $\begin{array}{l}\text { Pain in legs, mental } \\
\text { depression, stomach ache }\end{array}$ & $\begin{array}{l}\text { He looked unhealthy } \\
\& \text { is addicted to } \\
\text { smoking }\end{array}$ \\
\hline 2 & 19 & 2 & 10 & No & $\begin{array}{l}\text { Insomnia, pain in hands \& } \\
\text { legs, mental depression, } \\
\text { stomach ache, skin disease }\end{array}$ & $\begin{array}{l}\text { Pain in hands and } \\
\text { legs } \\
\text { problem }\end{array}$ \\
\hline 3 & 15 & 3 & 13 & No & $\begin{array}{l}\text { Indigestion, insomnia, pain in } \\
\text { hands \& legs, mental } \\
\text { depression }\end{array}$ & $\begin{array}{l}\text { He feels insomnia } \\
\text { and pain in hands }\end{array}$ \\
\hline 4 & 22 & 6 months & 8 & No & $\begin{array}{l}\text { Pain in hands \& legs, mental } \\
\text { depression }\end{array}$ & $\begin{array}{l}\text { He is NOT aware of } \\
\text { health effects due to } \\
\text { EMF }\end{array}$ \\
\hline 5 & 22 & 6 months & $6-7$ & $\begin{array}{l}\text { Yes } \\
(2-3 / \text { day })\end{array}$ & $\begin{array}{l}\text { Stomach ache, pain in hands \& } \\
\text { legs, mental depression }\end{array}$ & $\begin{array}{l}\text { He is aware of } \\
\text { health effects due to } \\
\text { EMF }\end{array}$ \\
\hline 6 & 30 & 4 & 10 & No & $\begin{array}{l}\text { Indigestion, insomnia, pain in } \\
\text { hands \& legs, mental } \\
\text { depression }\end{array}$ & $\begin{array}{l}\text { He is NOT aware of } \\
\text { health effects due to } \\
\text { EMF }\end{array}$ \\
\hline 7 & 26 & 4 & 8 & No & $\begin{array}{l}\text { pain in hands \& legs }(1 \mathrm{yr}) \text {, } \\
\text { mental depression ( } 3 \text { months), } \\
\text { skin disease ( } 6 \text { months) }\end{array}$ & $\begin{array}{l}\mathrm{He} \text { is aware of } \\
\text { health effects due to } \\
\text { EMF }\end{array}$ \\
\hline 8 & 26 & 6 months & 10 & No & pain in legs, mental depression & $\begin{array}{l}\text { He is NOT aware of } \\
\text { health effects due to } \\
\text { EMF }\end{array}$ \\
\hline 9 & 27 & 4 & 10 & No & Insomnia & $\begin{array}{l}\text { He is NOT aware of } \\
\text { health effects due to } \\
\text { EMF }\end{array}$ \\
\hline
\end{tabular}

In Table-4, epidemiological survey data were collected from the Nilkhet Dhaka from 20 photocopier shops. The operators were asked questions form questionnaire forms regarding their age, working years, number of hours working per day, smoker/non-smoker, various symptoms of their health and other observations. These data from table-4 Nilkhet, Dhaka were taken on the date 04.4.2013 
Table-4: Photocopy Operators at Nilkhet, Dhaka (4.4.2013)

\begin{tabular}{|c|c|c|c|c|c|c|}
\hline S.N. & $\begin{array}{l}\text { Age } \\
\text { (years) }\end{array}$ & $\begin{array}{l}\text { Working } \\
\text { years }\end{array}$ & $\begin{array}{l}\text { Working } \\
\text { hours/day }\end{array}$ & Smoker? & Symptoms & Other observations \\
\hline 1 & 37 & $\begin{array}{l}7-8 \\
\text { years }\end{array}$ & $8-10$ hours & Yes & Pain in legs and hands, cataracts & $\begin{array}{l}\mathrm{He} \text { is NOT aware of health } \\
\text { effects due to EMF }\end{array}$ \\
\hline 2 & 19 & 3 years & 10 hours & $\begin{array}{ll}\text { Yes: } & 2 \\
\text { years } & \end{array}$ & Pain in legs, mental depression & $\begin{array}{l}\text { He is aware of health effects } \\
\text { due to EMF }\end{array}$ \\
\hline 3 & 18 & 3 years & 12 hours & No & $\begin{array}{l}\text { Pain in legs and hands, cataracts, } \\
\text { mental depression }\end{array}$ & $\begin{array}{l}\text { He is NOT aware of health } \\
\text { effects due to EMF }\end{array}$ \\
\hline 4 & 25 & 6 years & 12 hours & No & $\begin{array}{l}\text { Pain in legs and hands, stomach } \\
\text { ache, vomit, indigestion }\end{array}$ & $\begin{array}{l}\text { He is aware of health effects } \\
\text { due to EMF }\end{array}$ \\
\hline 5 & 29 & $\begin{array}{l}1.5 \\
\text { months }\end{array}$ & 12 hours & $\begin{array}{l}\text { Yes: } 8- \\
\text { 10/day } \\
\text { (8 years) }\end{array}$ & None & $\begin{array}{l}\text { He is NOT aware of health } \\
\text { effects due to EMF }\end{array}$ \\
\hline 6 & 34 & 20 years & 12 hours & No & Mental depression & $\begin{array}{l}\mathrm{He} \text { is NOT aware of health } \\
\text { effects due to EMF }\end{array}$ \\
\hline 7 & 25 & 10 years & 12 hours & Yes & $\begin{array}{l}\text { Insomnia, pain in hands, eye } \\
\text { problem }\end{array}$ & $\begin{array}{l}\text { He is NOT aware of health } \\
\text { effects due to EMF }\end{array}$ \\
\hline 8 & 34 & 5 years & 12 hours & Yes & $\begin{array}{l}\text { Insomnia, pain in legs and } \\
\text { hands }\end{array}$ & $\begin{array}{l}\text { He is NOT aware of health } \\
\text { effects due to EMF }\end{array}$ \\
\hline 9 & 48 & 25 years & 10 hours & $\begin{array}{l}\text { Yes: } 10- \\
\text { 15/day }\end{array}$ & $\begin{array}{l}\text { Pain in hands, cataracts, mental } \\
\text { depression, skin disease, } \\
\text { stomach ache, Insomnia }\end{array}$ & $\begin{array}{l}\text { He is NOT aware of health } \\
\text { effects due to EMF }\end{array}$ \\
\hline 10 & 38 & 5 years & 8 hours & $\begin{array}{ll}\text { Yes: } & 15 \\
\text { years } & \end{array}$ & $\begin{array}{l}\text { Indigestion, cataract, mental } \\
\text { depression, sometimes: stomach } \\
\text { ache, pain in legs and hands }\end{array}$ & $\begin{array}{l}\text { He is aware of health effects } \\
\text { due to EMF }\end{array}$ \\
\hline 11 & 27 & 6 years & 8 hours & $\begin{array}{ll}\text { Yes: } & 8 \\
\text { years } & \end{array}$ & Pain in hands and legs & $\begin{array}{l}\text { He is NOT aware of health } \\
\text { effects due to EMF }\end{array}$ \\
\hline 12 & 20 & 4 years & 13 hours & $\begin{array}{ll}\text { Yes: } & 1 \\
\text { year } & \end{array}$ & Mental depression, skin disease & $\begin{array}{l}\text { The man looked weak. He is } \\
\text { NOT aware of health effects } \\
\text { due to EMF }\end{array}$ \\
\hline 13 & 25 & 6 years & 14 hours & $\begin{array}{ll}\text { Yes: } & 2 \\
\text { years } & \end{array}$ & Cataract, pain in legs and hands & $\begin{array}{l}\text { The man seemed weak. He } \\
\text { is NOT aware of health } \\
\text { effects due to EMF }\end{array}$ \\
\hline 14 & 21 & 2 years & 8 hours & $\begin{array}{ll}\text { Yes: } & 1 \\
\text { year } & \end{array}$ & Mental depression, skin disease & $\begin{array}{l}\mathrm{He} \text { is NOT aware of health } \\
\text { effects due to EMF }\end{array}$ \\
\hline 15 & 24 & 4 years & 8 hours & Yes: & Pain in hands & $\begin{array}{l}\mathrm{He} \text { is NOT aware of health } \\
\text { effects due to EMF }\end{array}$ \\
\hline 16 & 32 & 8 years & 11 hours & Yes & $\begin{array}{l}\text { Vomit, insomnia, cataract, } \\
\text { stomach ache, pain in legs, } \\
\text { mental depression, sometimes } \\
\text { indigestion }\end{array}$ & $\begin{array}{l}\text { He is aware of health effects } \\
\text { due to EMF but he does not } \\
\text { take any protection to } \\
\text { prevent it. }\end{array}$ \\
\hline 17 & 28 & 4 years & 10 hours & $\begin{array}{ll}\text { Yes: } & 8 \\
\text { years } & \end{array}$ & $\begin{array}{l}\text { Indigestion, cataract, pain in } \\
\text { legs and hands, skin disease }\end{array}$ & $\begin{array}{l}\text { He is NOT aware of health } \\
\text { effects due to EMF }\end{array}$ \\
\hline 18 & 28 & 12 years & 12 hours & No & $\begin{array}{l}\text { Cataract, pain in legs, mental } \\
\text { depression }\end{array}$ & $\begin{array}{l}\text { He is aware of health effects } \\
\text { due to EMF }\end{array}$ \\
\hline 19 & 20 & 4 years & 12 hours & No & Pain in legs & $\begin{array}{l}\mathrm{He} \text { is NOT aware of health } \\
\text { effects due to EMF }\end{array}$ \\
\hline 20 & 22 & 2 years & 12 hours & No & $\begin{array}{l}\text { Sometimes pain in legs and } \\
\text { hands }\end{array}$ & $\begin{array}{l}\text { He seemed like a smoker } \\
\text { and have insomnia. He is } \\
\text { NOT aware of health effects } \\
\text { due to EMF. }\end{array}$ \\
\hline
\end{tabular}


Finally in table-5, epidemiological survey data were collected from the Nilkhet Dhaka from 8 photocopier shops. The operators were asked questions form questionnaire forms regarding their age, working years, number of hours working per day, smoker/non-smoker, various symptoms of their health and other observations. These data from table-5 Uttara, Dhaka were taken on the date 01.4.2013

Table-5: Photocopy Operators at SR Tower photocopier shops, Uttara, Dhaka (8.03.2014)

\begin{tabular}{|l|l|l|l|l|l|l|}
\hline $\begin{array}{l}\text { S.N } \\
.\end{array}$ & $\begin{array}{l}\text { Age } \\
\text { (years) }\end{array}$ & $\begin{array}{l}\text { Working } \\
\text { years }\end{array}$ & $\begin{array}{l}\text { Working } \\
\text { hours/day }\end{array}$ & Smoker? & Symptoms & Other observations \\
\hline 1 & 23 & 1 year & 15 hours & No & $\begin{array}{l}\text { Indigestion, pain in legs and } \\
\text { hands, mental depression, eye } \\
\text { problem }\end{array}$ & $\begin{array}{l}\text { Sometimes he has pain in } \\
\text { his eyes. Usually he gets } \\
\text { very little rest. He is aware } \\
\text { of health effects due to } \\
\text { EMF }\end{array}$ \\
\hline 2 & 22 & 2 years & 10 hours & $\begin{array}{l}\text { Yes: 5- } \\
10 / \text { day }\end{array}$ & $\begin{array}{l}\text { Indigestion, pain in legs and } \\
\text { hands, mental depression }\end{array}$ & $\begin{array}{l}\text { He is NOT aware of health } \\
\text { effects due to EMF }\end{array}$ \\
\hline 3 & 28 & 6 years & 10 hours & No & $\begin{array}{l}\text { Indigestion, pain in legs and } \\
\text { hands, mental depression, } \\
\text { skin disease, eye problem }\end{array}$ & $\begin{array}{l}\text { He is aware of health } \\
\text { effects due to EMF }\end{array}$ \\
\hline 4 & 31 & 15 years & 8 hours & No & $\begin{array}{l}\text { Insomnia, pain in legs and } \\
\text { hands, mental depression, eye } \\
\text { problem }\end{array}$ & $\begin{array}{l}\text { He is NOT aware of health } \\
\text { effects due to EMF }\end{array}$ \\
\hline 5 & 24 & 4 years & 10 hours & $\begin{array}{l}\text { Yes: 10- } \\
\text { Indigestion, pain in legs and } \\
\text { hands, skin disease }\end{array}$ & $\begin{array}{l}\text { He is NOT aware of health } \\
\text { effects due to EMF }\end{array}$ \\
\hline 6 & 19 & 3 years & 6 hours & No & pain in legs and hands & $\begin{array}{l}\text { He is NOT aware of health } \\
\text { effects due to EMF }\end{array}$ \\
\hline 7 & 20 & 2 months & 13 hours & No & $\begin{array}{l}\text { None is NOT aware of health } \\
\text { effects due to EMF }\end{array}$ \\
\hline 8 & 25 & 1 year & 5 hours & No & $\begin{array}{l}\text { He is NOT aware of health } \\
\text { effects due to EMF }\end{array}$ \\
\hline
\end{tabular}

It has been observed from the epidemiological study that there are the common problems found for these operators:

(1) People working for 8-10 hours a day have various sufferings

(2) People working for 15 years have severe health problems like indigestion, stomach ache, insomnia, pain in hands, cataract, and sexual problems.

(3) People working for 20-25 years have mental depression.

\subsection{EMF Measurements}

In table 6, machine information for EMF is given for these 5 machines mentioned in table 1. Equipment information, country made, the threshold distances for both electric and magnetic fields were measured. Also, the maximum magnetic field value around the copier machine was measured for these machines. These data from table- 6 at Banani Super Market, Dhaka were taken on the date 12.12.2013

Table-6: Photocopy Machines at Banani Super Market, Dhaka (12.12.2013)

\begin{tabular}{|c|c|c|c|c|}
\hline \multirow[t]{2}{*}{$\begin{array}{l}\text { Serial } \\
\text { No. }\end{array}$} & \multirow{2}{*}{$\begin{array}{l}\text { Equipment info. } \\
\text { (Machine \#, Machine Model, } \\
\text { Country made, Date of } \\
\text { installation) }\end{array}$} & \multicolumn{2}{|c|}{$\begin{array}{l}\text { Threshold dis. in front of the screen } \\
\text { measured from the centre of the } \\
\text { equipment }(\mathrm{cm})\end{array}$} & \multirow[t]{2}{*}{$\begin{array}{l}\text { Magnetic } \quad \text { Field } \\
\text { maximum }(\mathrm{mG})\end{array}$} \\
\hline & & Electric field (EF) & $\begin{array}{l}\text { Magnetic } \\
\text { field(MF) }\end{array}$ & \\
\hline 1 & $\begin{array}{l}\text { Toshiba } 360 \text { e studio Japan } \\
2009\end{array}$ & 25 & 65 & $10.7 \mathrm{mG}$ \\
\hline 2 & Toshiba 450 Singapore & 18 inches & 45 & $4.2 \mathrm{mG}$ \\
\hline 3 & $\begin{array}{l}\text { Toshiba } 452 \text { e studio Singapore } \\
2009\end{array}$ & 24 inches & 60 & $2.7 \mathrm{mG}$ \\
\hline 4 & Toshiba 350 e studio Japan & 26 inches & 65 & $5.5 \mathrm{mG}$ \\
\hline 5 & $\begin{array}{l}\text { Toshiba } 350 \text { e studio Japan } \\
2008\end{array}$ & 17 inches & 50 & $10.7 \mathrm{mG}$ \\
\hline
\end{tabular}


In table-7, machine information for EMF is given for these 3 machines mentioned in table-2 were taken from shops at Mohakhali Dhaka. Equipment information, country made, the threshold distances for both electric and magnetic fields were measured. Also, the maximum magnetic field value around the copier machine was measured for these machines. These data from table-7 at Mohakhali, Dhaka were taken on the date 01.4.2013

Table-7: Photocopy Machines at Mohakhali, Dhaka (1.04.2013)

\begin{tabular}{|l|l|l|l|l|}
\hline $\begin{array}{l}\text { Serial } \\
\text { No. }\end{array}$ & $\begin{array}{l}\text { Equipment info. } \\
\text { (Machine \#, Machine Model, } \\
\text { Date of installation) }\end{array}$ & $\begin{array}{l}\text { Threshold dis. in front of the screen } \\
\text { measured from the centre of the equipment } \\
(\mathrm{cm})\end{array}$ & $\begin{array}{l}\text { Magnetic } \\
\text { maximum (mG) }\end{array}$ \\
\cline { 3 - 5 } & Electric field (EF) & Magnetic field(MF) & \\
\hline 1 & Studio 452, Toshiba 452, Japan & 55 & 400 & $135.50 \mathrm{mG}$ \\
\hline 2 & Studio 450, Toshiba 450, Japan & 70 & 600 & $145.60 \mathrm{mG}$ \\
\hline 3 & Toshiba e-Studio 305, Japan & 1300 & 1500 & $62 \mathrm{mG}$ \\
\hline
\end{tabular}

In table-8, machine information for EMF is given for these 9 machines mentioned in table-3 were taken from shops at Farmgate Green Road, Dhaka. Equipment information, country made, the threshold distances for both electric and magnetic fields were measured. Also, the maximum magnetic field value around the copier machine was measured for these machines. These data from table- 8 at Farmgate Green Road, Dhaka were taken on the date 01.4.2013

Table-8: Photocopy Machines at Farmgate Green Road, Dhaka (1.04.2013)

\begin{tabular}{|c|c|c|c|c|}
\hline \multirow[t]{2}{*}{$\begin{array}{l}\text { Serial } \\
\text { No. }\end{array}$} & \multirow{2}{*}{$\begin{array}{l}\text { Equipment info. } \\
\text { (Machine \#, Machine Model, } \\
\text { Country made, Date of } \\
\text { installation) }\end{array}$} & \multicolumn{2}{|c|}{$\begin{array}{l}\text { Threshold dis. in front of the screen } \\
\text { measured from the centre of the } \\
\text { equipment }(\mathrm{cm})\end{array}$} & \multirow[t]{2}{*}{$\begin{array}{l}\text { Magnetic } \\
\text { maximum }(\mathrm{mG})\end{array}$} \\
\hline & & Electric field (EF) & $\begin{array}{l}\text { Magnetic } \\
\text { field(MF) }\end{array}$ & \\
\hline 1 & $\begin{array}{l}\text { Toshiba } 3560 \text { Japan } \\
1990\end{array}$ & 45.1 & 72.1 & $7 \mathrm{mG}$ \\
\hline 2 & $\begin{array}{l}\text { Toshiba } 2652 \text { China } \\
1998\end{array}$ & 47 & 83 & $8 \mathrm{mG}$ \\
\hline 3 & $\begin{array}{l}\text { Toshiba } 3560 \text { Japan } \\
2010\end{array}$ & 42 & 58 & $10 \mathrm{mG}$ \\
\hline 4 & $\begin{array}{l}\text { Canon NP- } 3050 \text { Japan } \\
2010\end{array}$ & 38 & 45 & $8 \mathrm{mG}$ \\
\hline 5 & $\begin{array}{l}\text { Toshiba } 3560 \text { China } \\
2007\end{array}$ & 45 & 50 & $8 \mathrm{mG}$ \\
\hline 6 & $\begin{array}{l}\text { Toshiba } 3560 \text { Japan } \\
2010\end{array}$ & 43 & 58 & $9 \mathrm{mG}$ \\
\hline 7 & $\begin{array}{l}\text { Toshiba DS } 1012 \text { China } \\
2008\end{array}$ & 40 & 76 & $9 \mathrm{mG}$ \\
\hline 8 & $\begin{array}{l}\text { Toshiba } 3560 \text { Japan } \\
2001\end{array}$ & 41 & 56 & $9 \mathrm{mG}$ \\
\hline 9 & $\begin{array}{l}\text { Toshiba } 2860 \text { China } \\
2009\end{array}$ & 45 & 52 & $8 \mathrm{mG}$ \\
\hline
\end{tabular}

In table-9, machine information for EMF is given for these 20 photocopier machines mentioned in table-4 were taken from shops at Nilkhet photocopier shops, Dhaka. Equipment information, country made, the threshold distances for both electric and magnetic fields were measured. Also, the maximum magnetic field value around the copier machine was measured for these machines. These data from table-9 at Nilkhet photocopier shops, Dhaka were taken on the date 04.4.2013 
Table-9: Photocopy Machines at Nilkhet photocopier shops, Dhaka (4.04.2013)

\begin{tabular}{|c|c|c|c|c|}
\hline \multirow[t]{2}{*}{$\begin{array}{l}\text { Serial } \\
\text { No. }\end{array}$} & \multirow{2}{*}{$\begin{array}{l}\text { Equipment info. } \\
\text { (Machine \#, Machine Model, } \\
\text { Country made, Date of } \\
\text { installation) }\end{array}$} & \multicolumn{2}{|c|}{$\begin{array}{l}\text { Threshold dis. in front of the screen } \\
\text { measured from the centre of the } \\
\text { equipment }(\mathrm{cm})\end{array}$} & \multirow[t]{2}{*}{$\begin{array}{l}\text { Magnetic Field } \\
\text { maximum }(\mathrm{mG})\end{array}$} \\
\hline & & Electric field (EF) & $\begin{array}{l}\text { Magnetic } \\
\text { field(MF) }\end{array}$ & \\
\hline 1 & Toshiba 3560 Japan 2010 & 47 & $>180$ & $194 \mathrm{mG}$ \\
\hline 2 & Toshiba 3560 Japan & 24 & $>180$ & $45 \mathrm{mG}$ \\
\hline 3 & Toshiba 3560 Japan & 54 & $>180$ & $196 \mathrm{mG}$ \\
\hline 4 & Toshiba 3560 Japan & 47 & $>180$ & $26.5 \mathrm{mG}$ \\
\hline 5 & Toshiba 3560 Japan 1998 & 39 & $>180$ & $140.3 \mathrm{mG}$ \\
\hline 6 & Toshiba 3560 Japan & 65 & $>180$ & $172.9 \mathrm{mG}$ \\
\hline 7 & Toshiba 3560 Japan & 50 & $>180$ & $46 \mathrm{mG}$ \\
\hline 8 & Toshiba 3560 Japan & 54 & $>180$ & $157 \mathrm{mG}$ \\
\hline 9 & Toshiba 3560 Japan & 42 & $>180$ & $192 \mathrm{mG}$ \\
\hline 10 & Toshiba 3560 Japan & 36 & $>180$ & $2 \mathrm{mG}$ \\
\hline 11 & Toshiba 3560 Japan & 36 & $>180$ & $30 \mathrm{mG}$ \\
\hline 12 & Toshiba JE074177 Malaysia & 66 & $>180$ & $176 \mathrm{mG}$ \\
\hline 13 & Lanier 3560 Japan 2002 & 31 & $>180$ & $11.5 \mathrm{mG}$ \\
\hline 14 & Toshiba JE074177 Malaysia & 66 & $>180$ & $176 \mathrm{mG}$ \\
\hline 15 & Toshiba 3560 Japan & 46 & $>180$ & $134 \mathrm{mG}$ \\
\hline 16 & Toshiba 5660 Japan & 56 & $>180$ & $170 \mathrm{mG}$ \\
\hline 17 & Panasonic SP204 China & 53 & $>180$ & $153 \mathrm{mG}$ \\
\hline 18 & Toshiba 3560 Japan & 51 & $>180$ & $191 \mathrm{mG}$ \\
\hline 19 & Toshiba 3560 Japan 1999 & 50 & $>180$ & $85 \mathrm{mG}$ \\
\hline 20 & Toshiba 3560 Japan & 38 & $>180$ & $78 \mathrm{mG}$ \\
\hline
\end{tabular}

Finally in table-10, machine information for EMF is given for these 8 photocopier machines mentioned in table-5 were taken from SR Tower photocopier shops, Uttara, Dhaka. Equipment information, country made, the threshold distances for both electric and magnetic fields were measured. Also, the maximum magnetic field value around the copier machine was measured for these machines. These data from table-10 Uttara, Dhaka were taken on the date 8.3.2014

Table-10: Photocopy Machines at SR Tower photocopier shops, Uttara, Dhaka (8.03.2014)

\begin{tabular}{|c|c|c|c|c|}
\hline \multirow[t]{2}{*}{$\begin{array}{l}\text { Serial } \\
\text { No. }\end{array}$} & \multirow{2}{*}{$\begin{array}{l}\text { Equipment info. } \\
\text { (Machine \#, Machine Model, } \\
\text { Country made, Date of } \\
\text { installation) }\end{array}$} & \multicolumn{2}{|c|}{$\begin{array}{l}\text { Threshold dis. in front of the screen } \\
\text { measured from the centre of the } \\
\text { equipment }(\mathrm{cm})\end{array}$} & \multirow[t]{2}{*}{$\begin{array}{l}\text { Magnetic Field } \\
\text { maximum }(\mathrm{mG})\end{array}$} \\
\hline & & Electric field (EF) & $\begin{array}{l}\text { Magnetic } \\
\text { field(MF) }\end{array}$ & \\
\hline 1 & Toshiba DP-4540 China 2006 & 46 & 18 & $168 \mathrm{mG}$ \\
\hline 2 & Studio 352; DP-4430 Japan 2011 & 32 & 15 & $106 \mathrm{mG}$ \\
\hline 3 & $\begin{array}{l}\text { Toshiba e- studio } 452 ; \text { DP- } 4540 \\
\text { Japan } 2009\end{array}$ & 35 & 19 & $137 \mathrm{mG}$ \\
\hline 4 & Toshiba DP-4540 Japan 2005 & 48 & 17 & $172 \mathrm{mG}$ \\
\hline 5 & $\begin{array}{l}\text { Toshiba studio } 352 ; \quad \text { DP-4438 } \\
\text { Japan } 2011\end{array}$ & 30 & 14 & $102 \mathrm{mG}$ \\
\hline 6 & $\begin{array}{l}\text { Toshiba e- studio } 350 ; \text { A7820 } \\
\text { Japan } 2010\end{array}$ & 33 & 11 & $130 \mathrm{mG}$ \\
\hline 7 & $\begin{array}{l}\text { Toshiba e- studio } 452 ; \text { DP-4540 } \\
\text { China } 2010\end{array}$ & 52 & 22 & $177 \mathrm{mG}$ \\
\hline 8 & $\begin{array}{l}\text { Toshiba e- studio 452; DP- } 4540 \\
\text { China } 2006\end{array}$ & 34 & 14 & $150 \mathrm{mG}$ \\
\hline
\end{tabular}




\section{DISCUSSIONS}

From epidemiological studies given in tables 1-5 it has been found that common diseases from among the workers are indigestion, vomit, insomnia, pain in hands and legs, stomach ache, mental depression, skin disease, cataract, sexual problems, hairs turning white etc. In many of the photocopier shops the operators were working in congested space with lots of machineries around. There are many devices and power lines around them, having a congested environment and low circulation of air. Some of the operators are smokers and have been for a couple of years, which might have had some negative effects on their health.

From the EMF measurement studies given in tables 6-10, it was found from the results that the magnetic field values are much higher than the threshold level. Because of the nature of the wiring both in the ceiling and floor, all the rooms had higher magnetic field than threshold value. Operators work on an average of 10-13 hours a day in those shops. We have in mind to include other regions for the study to continue.

A potential hazard to health can be produced either as a result of the exposure of the human body to NIR, or by interaction with technical devices, which are themselves affected by NIR and they give rise to health hazards (e.g. interference with electro medical devices, unintentional triggering of electrically activated detonator and ignition of flammable materials). This is especially true if the individuals concerned are not aware of the potential hazard to be unable to identify it.

\section{CONCLUSION}

From the above lab results, it has been found that in most cases the magnetic field has crossed threshold value. The electric field also has a higher threshold value in some of the equipemnts. Also, the magnetic field maximum exposure was nearly $200 \mathrm{mG}$ in many cases. Wiring must be done according to the building code 2012.It is hoped that this survey will be helpful as a preventive measure for photocopier operators who might get affected tomorrow. Same kind of experimental data on epidemiological survey can be done in other parts of Bangladesh.

In order to get rid of the health hazards caused by all those systems, people should be aware of them and accordingly precautionary measures should be taken. It is necessary to be acquainted with the harmful effects of non-ionizing radiations on living systems and also on the environment that we are living in and to find appropriate corrective measures for minimizing or controlling the hazards of NIR as far as practicable.

Since magnetic field is more harmful than electric field, there must be a limit both in the residential and occupational levels between 0.2 to $0.3 \mu \mathrm{T}$ or $2.5 \mathrm{mG}$. (This value is internationally recognized as standard limit in many countries). However, for the staff working at very high frequency transmitting stations, safe precautions such as wearing of special clothing, screened helmets and secured goggles should be taken. The duration of exposure must be kept to the minimum possible. It must be ensured that intensity of radiation in the body does not exceed the recommended maximum level $\left(10 \mathrm{~mW} / \mathrm{cm}^{2}, 195 \mathrm{~V} / \mathrm{m}\right.$ in U.S.A. and $0.1 \mathrm{~mW} / \mathrm{cm}^{2}, 20 \mathrm{~V} / \mathrm{m}$ in CIS).

\section{REFERENCES}

[1]. M. Coleman; V. Bera. A Review of Epidemiological Studies of the Health Effects of Living Near or Working with Electricity Generation and Transmission Equipment. International Journal of Epidemiology. 17 (1): 1-13 (1988) [2]. G. Draper; T. Vincent; M.E. Kroll; J. Swanson. Childhood cancer in relation to distance from high voltage power lines in England and Wales: a case-control study. BMJ. 330 (7503): 1290 (2005) [3] J.M. Al-Bareeq. Health Risks of Electromagnetic Field. Editorial. Bahrain Medical Bulletin. 20(1), (1998)

[3]. J.M. Al-Bareeq. Health Risks of Electromagnetic Field. Editorial. Bahrain Medical Bulletin. 20(1), (1998)

[4]. Z. Ziang. Considering factors in Chinese EMF standard. 3rd International EMF Seminar in China: Electromagnetic Fields and Biological Effects. Guilin, China: October 13-17, 2003. [Retrieved on 05.08.2012][http://www.who.int/pehemf/meetings/archive/en/proceedings_eng.pdf\#page=89] (2003)

[5]. E. van Wijngaarden; D. A. Savitz; R.C. Kleckner; J. Cai; D. Loomis. Exposure to electromagnetic fields and suicide among electric utility workers a nested case-control study. West J Med. 173(2): 94-100 (2000)

[6]. K. J. Fernie; S. J. Reynolds. The Effects of Electromagnetic Fields from Power Lines on Avian Reproductive Biology and Physiology: a Review.Journal of Toxicology and Environmental Health, Part B, 8:127-140 (2005)

[7]. Photocopier. Wikipedia. Retrieved on 27.2.2015 from source: http://en.wikipedia.org/wiki/Photocopier

[8]. "Photocopier Hazards and a Conservation Case Study (notes 17,18)". Retrieved 2009-11-20 from source: http://cool.conservation-

us.org/coolaic/sg/bpg/annual/v08/bp08-05.html\#note17

[9]. "Photocopier and Laser Printer Hazards". London Hazards Centre. 2002. Retrieved 2009-11-20 from source: http://www.lhc.org.uk/members/pubs/factsht/76fact.pdf [10]. "Health and Safety Representatives' Handbook" (PDF). National Association of Schoolmasters Union of Women Teachers (NASUWT). July 27, 2009. Retrieved April 30, 2011 from source: http://www.nasuwt.org.uk/consum/idcplg?IdcService=GET FILE\&dDocName=NASUWT_000235\&RevisionSelection Method=latest\&allowInterrupt $=1$

\section{BIOGRAPHIES}

Dr. M. Quamruzzaman, was Director General of AERE with 25 years of research experience. He is currently serving as Associate Professor and Chairman, Departments of Electrical \& Electronic Engineering (EEE) and Electrical and Telecommunication Engineering (ETE). His Fields of Specialization are Electrical and Electronic Technology, Communication Engr. \&VLSI Technology, Nuclear Electronics and Instrumentation, Industrial Management and Control System. 
Dr. Munima Haque, was a post doctoral researcher at the Micro and Nanotechnology Laboratory at the University of Illinois Urbana Champaign, USA working on Biomedical Engineering having concentration on cancer biology with nanotechnology applications. She is currently employed as an Assistant Professor in Southeast University. Dr. Haque's fields of specialization are Health and Medical Physics, Radiobiology, Cancer Biology, Bionanotechnology, Biomedical Engineering, Nuclear Physics and Nuclear Engineering, 